two weeks, performed paracentesis in each eye, and removed from beneath the retinae a fair amount of straw-coloured fluid. The right eye improved and one could see the puncture mark with the ophthalmoscope. The left remained blind, with complete detachment. About this time he developed a febrile illness, and was taken into hospital. It was not typical of anything, and was supposed to be a form of typhoid. After this he went home to England, and I heard to my surprise that both eyes had been excised for pain, one at Moorfields, the other at Guy's Hospital, and the remains of a cysticercus found. The attack of fever was probably a cysticercus fever, but from first to last there was no sign suggestive of cysticercus, though, of course, the bilateral affection would tend to put one off the track.

I have since found the report made on this case at Moorfields Hospital (p. 514, No. 6814 I.P.), which throws much doubt on the cysticercus theory. There had been severe choroido-retinitis, with organization of the subretinal exudate. There is a large space near the papilla, and one near the ora serrata which are filled with fibrin, and may have been cysticercus cysts, but there is nothing diagnostic about them. The retina is partly detached, but is mainly adherent to the surface of the newly-formed tissue.

I have not seen the report on the other eye.

\title{
ANNOTATION
}

\section{LIGHTING IN FACTORIES AND WORKSHOPS}

THE Departmental Committee on lighting in factories and workshops have now issued their third report. We greatly regret to note that owing to the urgent need for economy the present report is the final one, and we share the Committee's hope that further work on this most important subject may be resumed at a later date. As the Committee have included in this final report the recommendations made in the two previous reports, we have decided, in view of the great importance of the subject, to publish the part of the report embodying these recommendations in full. In addition to this part of the report, there are five valuable appendices which should prove of great assistance in pointing out to future workers on the subject fruitful lines of experiment. The first appendix gives a classification of the nature of the work in thirty-two different industries as regards " fine work " and " very fine work." The second appendix deals with observations on artificial light in spinning and weaving, and incidental processes 
in the cotton, woollen and worsted industries. This includes a set of diagrams showing graphically to what extent any given illumination is used for each process investigated, and also a number of analytical tables of the results obtained. The third appendix gives a summary of foreign lighting codes, and also a table of the recommendations of the American Illuminating Engineering Society for good lighting practice both general and on the work. These will be found to be considerably higher than the statutory minima for the respective types of work. The fourth appendix gives details of experiments to determine the relative efficiency of artificial light, daylight, and mixed light, carried out in the factory lighting experimental room at the National Physical Laboratory. The fifth and last appendix describes an experimental apparatus for the lighting of glass-bevelling shops, an industry in which complaints have been made as to lighting conditions.

Although much work still remains to be done on this important subject, the present report is a considerable advance on all previous work, and it is to be hoped that legislative measures will pay due attention to the recommendations that accompany it. The report itself should certainly be in the hands of all those who have the management of factories.

\section{REPORT OF THE DEPARTMENTAL (HOME OFFICE) COMMITTEE ON LIGHTING IN FACTORIES AND WORKSHOPS-THIRD REPORT}

\section{FORMER RECOMMENDATIONS.}

As our inquiries, owing to the urgent need for economy, are for the present concluded, we think it advisable to repeat here the recommendations we have already made in previous reports.

FIRST REPORT.

In our First Report we recommended that,

1. There should be a statutory provision-

(a) requiring adequate and suitable lighting in general terms in every part of a factory or workshop, and

(b) giving power to the Secretary of State to make Orders defining adequate and suitable illumination for factories and workshops or for any parts thereof or for any processes carried on therein.

We also considered the minimum intensity of illumination desirable for the sake of general convenience and safety in parts of the workshops where work is normally carried on, and in yards, 